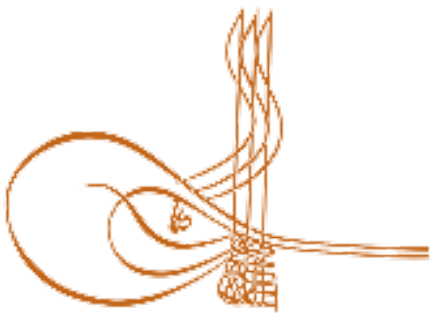

www.turkishstudies.net/education
Turkish Studies - Educational Sciences

eISSN: $2667-5609$

Research Article / Araștırma Makalesi

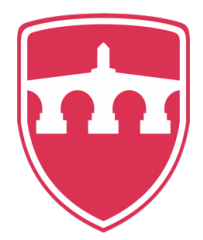

INTERNATIONAL BALKAN

UNIVERSITY

Sponsored by IBU

\title{
Türkçe Öğretmenlerinin Sınıf Yönetim Tarzları ile Öğretmenlik Mesleğine Yönelik Tutumları Arasındaki İlișkinin İncelenmesi"
}

\author{
The Mode of Classroom Management of Turkish Teachers in Relation with Their Attitudes about \\ Teaching A Profession
}

\author{
Ümit Yegen $^{* *}-$ Mehmet Özdemir ${ }^{* * *}$
}

\begin{abstract}
This survey is aiming to reveal the modes of class management of Turkish teachers in relation with their attitudes about teaching profession. This survey is carried out with randomly selected 267 teachers who work in the districts of Bursa and quantitative approach along with relational survey model is implemented. The data has been collected with a help of "Survey of Class Management" and "Attitude Scale of Teaching Profession". When analyzed the data, descriptive statistics is used and when it comes to comparisons, Test T and Unilateral variance analyze is conducted. According to the Survey, Turkish teachers embark on understanding of appreciated and authoritarian classroom management. In General, Although the correlation between the mode of classroom management and professional attitude scores aren't so high, It has been observed that teachers who like their job, have an understanding of appreciated classroom management. In the research in which it is also attempt to determine the attitudes of Turkish teachers towards teaching profession, while the difference arises in favor of female teachers at the sub-dimension of Turkish teachers being interested in the profession by gender variable, the significant difference has emerged at the sub-dimension of the interest and commitment to the profession by seniority variable. The significant difference was determined between Turkish teachers who have seniority of 1-5 years and Turkish teachers who have seniority of 11-20 years in the subdimension of interest in the profession and Turkish teachers who have 1-5 years seniority and Turkish teachers who have 6-15 years seniority in the sub-dimension of commitment to the profession. Learning environment which has positive, insightful, valued and effective communication will enable the individual to learn in a multifaceted way, as well as to gain the ability of self-regulation. The other problems related to this survey are tabulated. May-June 2019, the data was collected on a voluntary basis from the owners of the relevant scales. The article was uploaded to the Turkish Studies- Education article system on 29.11 .2019 by the first author.
\end{abstract}

\footnotetext{
* Makalenin verileri gönüllülük esasıyla Mayıs- Haziran 2019 aralığında toplanmış olup dergi sistemine Kasım 2019' da yüklenmiştir.

** Doktora Öğrencisi, Sakarya Üniversitesi, Eğitim Bilimleri Enstitüsü, Türkçe Eğitimi PhD Student, Sakarya University, Institute of Educational Sciences, Turkish Education ORCID 0000-0002-3500-1789

umit_yegen@hotmail.com

*** Dr. Öğr. Üyesi, Sakarya Üniversitesi, Eğitim Fakültesi, Türkçe Öğretmenliği

Asst. Prof. Dr, Sakarya University, Faculty of Education, Turkish Language Teaching

ORCID 0000-0002-5838-0304

mehmetoz@sakarya.edu.tr

Cite as/ Atıf: Yegen, Ü. \& Özdemir M. (2020). Türkçe öğretmenlerinin sınıf yönetim tarzları ile öğretmenlik mesleğine yönelik tutumları arasındaki ilişkinin incelenmesi, Turkish Studies - Education, 15(2), 1329-1347. https://dx.doi.org/10.29228/TurkishStudies.39950

Received/Geliş: 29 November/Kasım 2019

Accepted/Kabul: 22 April/Nisan 2020

Copyright $($ INTAC LTD, Turkey 
Structured Abstract: Introduction Classroom management is an open sphere for innovation and changes where each and every teacher is supposed to be qualified. Classroom management is one of the ways providing an effective learning sphere for the up-to-date generation who is changing with developing technology. Teacher is supposed to make the classroom effective and active. Teacher may present an understanding of management with his/her belief for the goals of the school, education he/she took, experience he/she gained in the context of classroom management concerning general rules of the school within the framework of classroom management. Thus, it is crucial to find out how much the modes of classroom management of Turkish teachers are effective on their professions. Why it is crucial is simply because they believe that they constantly need to improve themselves due to their professions; Sociologically, they're aware that their professions are needed and crucial, and lastly it is about their point of views of the teachers when they were trained. For that purpose, it has been striven to find out the relation between careless, appreciated or idle classroom management modes and their professional attitudes.

\section{Method}

In this survey, quantitative approach has been embarked on, thus, it is been figured on the model of relational survey since the recent situation has been identified. 267 participants in total; 124 female teachers $(\% 46,4) ; 143$ male teachers $(\% 53,6)$ have been asked. The data of this survey has been collected with "' Professional Scale Attitude" (Temizkan, 2008) and "' The Scale of Mode of Classroom Management"' (Ekici, 2003). When evaluated the opinion of the participants, descriptive statistics is used and when it comes to comparisons, Test $\mathrm{T}$ and Unilateral variance analyze and Pearson correlation are used.

\section{Results}

Of Turkish teachers have appreciated mode of classroom management by $\% 50.56$, authoritarian by 38.95 , careless by $\% 6$ and idle by $\% 4.49$. The student is under the control of teacher in terms of communication, pedagogical level, needs and learning motivation at the school. Thus, it is very important to provide this discipline. Two of the core skills that an individual need to get acquired is speaking and reading is taught by Turkish teachers and and effective classroom management mode is the way to get it. Classroom management modes become different in favor of female teachers at the point of sub-dimension of classroom management in the mode appreciated by variable sex; whereas it becomes meaningfully different in favor of male teachers at the point of sub-dimension of classroom management in the mode authoritarian. It becomes meaningfully different in favor of graduates from the Faculty of Education at the point of sub-dimensions of classroom management in the mode authoritarian (Chart 2). Classroom management is one of the most challenging matters that teachers need to overcome. Most senior teachers (11 years and above) didn't prefer the authoritarian classroom management. So, it is concluded that authoritarian classroom mode has been given in as the teacher have come more experienced in time. There is a meaningful difference between Turkish teachers experienced in teaching for 11-15 years and experienced in teaching for 16 years and above by sub-dimension classroom management in the mode of careless.

\section{Conculusion and Discussion}

Teachers' feelings about their profession should be grounded with the principle of believing that their profession is important and necessary for society and being able to be beneficial to their students by constantly improving themselves. While Turkish is placed in this frame, to ensure that candidate Turkish teachers who perceive Turkish as "native language" can contribute to the positive development of teaching attitude. It is likely that the professional behavior of a candidate Turkish teacher who believes that he / she will contribute to the development of individuals at an internal point also improves positively.

The relation between the modes of classroom management of Turkish teachers and their professional attitudes are generally not so high. It is found that there is a meaningful relation of the classroom management mode the appreciated with sub-dimension of enjoying the profession. Enjoying the profession $\mathrm{r}=791 \mathrm{p}<.05$, considering the determination coefficient $\left(\mathrm{r}^{2}=0.62\right)$ explains $62 \%$ of total variance in showing interest to a profession. Mode of authoritarian classroom management is related to " showing interest to the profession" and " believing in necessity of a profession" in attitudes of sub-dimensions. Showing interest to the profession, $\mathrm{r}=692 \mathrm{p}<.05$, considering the determination coefficient $\left(\mathrm{r}^{2}=0.47\right)$ explains $47 \%$ of total variance in showing interest to a profession. Believing in necessity of a profession $r=752 \mathrm{p}<.05$, considering the determination coefficient $\left(\mathrm{r}^{2}=0.56\right)$ explains $56 \%$ of total variance in believing in necessity of a profession. It can be inferred that teachers who enjoy their professions, tend to have a positive relation with an appreciated mode of classroom

Turkish Studies - Education, 15(2) 
management. Similarly, Turkish teachers who embark on mode of authoritarian classroom management tend to have a positive relation with sub-dimension of showing interest to a profession and believing in necessity of a profession.

Keywords: Turkish Education, Mode of Classroom Management, Professional Attitude, Turkish Teachers, Secondary School

Öz: Bu çalışmanın amacı Türkçe öğretmenlerinin sınıf yönetim tarzlarının mesleki tutumla ilişkisini ortaya koymaya çalışmaktır. Nicel yaklaşımın benimsendiği ilişkisel tarama modeline göre desenlenen çalışma, Bursa ili merkez ilçelerinde görev yapan seçkisiz yolla belirlenen 267 Türkçe öğretmenine uygulanmıştır. Veriler "Sınıf Yönetim Profilleri Anketi” ile "Öğretmenlik Mesleği Tutum Ölçeği” yardımıyla toplanmıştır. Verilerin analizinde ise betimsel istatistikler, karşılaştırmalarda ise t testi ve tek yönlü varyans analizi yapılmıştır. Araştırma sonuçlarına göre Türkçe ögrretmenleri; takdir edilen ve otoriter sınıf yönetim anlayışını benimsemişlerdir. Genel olarak sınıf yönetim tarzı ile mesleki tutum puanları arasındaki korelasyon çok yüksek olmamakla birlikte mesleğini seven öğretmenlerin takdir edilen sınıf yönetim anlayışına sahip oldukları gözlemlenmiştir. Türkçe öğretmenlerinin öğretmenlik mesleğine karşı tutumlarının da belirlenmeye çalışıldığ araştırmada, Türkçe öğretmenleri cinsiyet değişkenince mesleğe ilgi duyma alt boyutunda bayan öğretmenler lehine fark ortaya çıkarken, kıdem değişkenince mesleğe ilgi duyma ve mesleğe bağlılık alt boyutunda anlamlı fark ortaya çıkmıştır. Mesleğe ilgi duyma alt boyutunda 1-5 yıl kıdeme sahip Türkçe öğretmenleri ile 11-20 yıl kıdeme sahip Türkçe öğretmenleri arasında; mesleğe bağlılık alt boyutunda ise 1-5 yıl kıdeme sahip Türkçe öğretmenleri ile 6-15 yıl kıdeme sahip Türkçe öğretmenleri arasında anlamlı fark belirlenmiştir. Öğrenme ortamının olumlu, anlayışlı, değer verilen ve etkili iletişime sahip olması bireyin çok yönlü bir biçimde öğrenmesini sağlayabileceği gibi bireye öz düzenleme becerisi de kazandıracaktır. Araştırmaya konu olan diğer problemler tablolaştırılarak sunulmuştur. İlgili ölçeklerin sahiplerinden gerekli izin alınmış olup veriler; MayısHaziran 2019 aralığında gönüllük esasıyla toplanmıştır. Makale 29.11.2019 tarihinde Turkish Studies- Education makale sistemine birinci yazar tarafindan yüklenmiştir

Anahtar Kelimeler: Türkçe Eğitimi, Sınıf Yönetim Tarzları, Meslekî Tutum, Türkçe Öğretmenleri, Ortaokul

\section{Giriş}

Eğitim-öğretim sürecinde önemli noktalardan biri olan sınıf yönetimi, pek çok faktörden etkilenir. Bu faktörlerin temeli de öğretmen ve öğretmenin yeterliliğidir. Sınıf yönetimi her öğretmenin yeterli olması gereken ve sürekli değişimlere-yeniliklere açık olan bir alandır. Gelişen teknoloji ile birlikte değişen neslin, eğitim-öğretim ortamında etkili bir öğrenme gerçekleştirmesinin yollarından biri etkili sınıf yönetiminden geçmektedir. Sınıfı etkili ve etkin kılacak da öğretmendir. Öğretmen sınıf yönetimi çerçevesinde; okul amaçlarına ilişkin inancı, sınıf yönetimi bağlamında aldığı eğitim ve edindiği tecrübe ile okulun genel kuralları noktasında bir yönetim anlayışı sergileyebilir. Sınıf yönetiminin içeriği; fiziksel yeterlilik, plan-program, zaman yönetimi, sınıf ortamında ilişkilerin belirli kurallar çerçevesinde belirlenmesi, iletişimin düzenlenmesi ve davranış düzenlemelerine ilişkin etkinliklerden oluşur (Çelik, 2003; Erden, 2003; Karip, 2005). Sınıf yönetimi büyük ölçüde, öğrencilerin kişisel ve psikolojik gereksinimlerine dayandırılmalıdır. Öğretmenler, iyi bir sınıf yönetimi sağlamak için öğrenci gereksinimlerini ve bu gereksinimlerle ilintili olan davranışların ilişkisini anlamaları ve sınıfta öğrencilerin kişisel gereksinimlerini karşılayacak düzenlemeler yapmaları gerekir (Celep, 2002). Öğrenme ortamları değişkenlik göstermekle birlikte öğretmen; söz konusu değişenlikleri belirli ve etkili bir noktada temellendirebilmelidir. Bu nokta çerçevesinde etkili bir sınıf yönetimi iklimi oluşabilir. Okul kuralları çerçevesinde oluşturulan sınıf kuralları, öğrencilerin kişisel gereksinim ve beklentileri ile ilişkilendirilip o şekliyle sunulmalıdır.

Öğretmenin öğrenme ortamına pozitif bir etkiyi hâkim kılması için etkin bir sınıf yönetimi anlayışı göstermesi gereklidir. Çünkü sınıf kültür ve öğrenme ikliminin en önemli belirleyicisi öğretmendir ve öğretmenin davranıșları öğrencilerin öğrenme ortamlarındaki tutumlarını önemli ölçüde etkilemektedir (Dönmez, 2007). Öğretmenin sınıf yönetimi amacıyla sergilediği davranışlar, 
öğrenci başarısının belirleyicisi olduğuna göre, öğretmenin öğrenci başarısını artıracak davranışlar sergilemesi beklenir (Fenwick, 1998). Gereksinimleri çeşitli olan öğrencilere hitap edebilmek öğretileni etkili kılabilmek öğretmenin sınıf hâkimiyetini sağlaması ile mümkün olabilir. Söz konusu hâkimiyet öğrencilerin pedagojik durumlarına uygun bir biçimde sağlanmalıdır. Eğitim-öğretim ortamında öğrenci yapılarının çeşitlilik arz etmesi öğretmeni sınıf yönetimi anlamında zorlayabilir. Bu noktada öğretmen sınıf ortamındaki her türlü düzenlemeyi iyi planlamalıdır.

Öğretmenlerin sınıf ortamında, öğretim etkinlikleri sırasında, iletişim sürecinde ortaya koydukları davranışlar o kişinin sınıf yönetimi tarzını göstermektedir. Öğretmen sınıfın yöneticisi konumundadır ve farklı sınıf yönetimi tarzları uygulayabilmektedir (Ekici, 2004). Öğretmenlerin sınıf yönetimi tarzları farklı şekillerde sınıflandırılabilmektedir. Bu çalışmada Kris'in (1997) yapmış olduğu dörtlü sınıflandırma aşağıda açıklanarak kullanılmıştır. Bu sınıflandırmada öğretmenler "otoriter, takdir edilen, başıboş ve aldırmaz" sınıf yönetimi tarzlarından birine sahiptir.

Otoriter sınıf yönetimi, öğretmenin öğrenciler üzerindeki kontrol ve sınırlamalarıyla dikkat çekmektedir. $\mathrm{Bu}$ tarzda öğretmen, öğrencileri sık sık sıralarda düzenli oturmaları konusunda uyarmaktadır. Takdir edilen sınıf yönetiminde öğretmenin öğrenci üzerinde bir takım mantıklı nedenlere dayalı kontrolleri ve sınırlılıkları yer almakta, ancak öğrenci bağımsız olarak kendiliğinden cesaretlendirilmektedir. Bu tarzda sık sık kuralların arkasındaki nedenler açıklanmakta, düzeni bozan öğrenci kibarca uyarılmakta ancak kesinlikle azarlanmamaktadır. Başıboş sınıf yönetimi öğretmenin öğrencileri kontrol etmek için çok az davranış gösterdiği ve öğrencilerden çok az talepte bulunduğu tarzı yansıtmaktadır. Bu sınıf yönetimi tarzını özetleyen ifade "Kendi düşündüklerini yap" ifadesidir. $\mathrm{Bu}$ tarzda öğretmen öğrencilerin davranışlarını ve tepkilerini kabullenmekte ve sadece izlemektedir. Aldırmaz sınıf yönetimi tarzında öğretmenler sınıfa pek katılmadıkları için öğrencilere karşı genelde duyarsızdırlar. Bundan dolayı öğrencilerin çok talepleri vardır. Bu tarzda, öğretmen öğrenciler üzerinde hiçbir konuda baskı kurmak istememekte; ders malzemelerinin hazırlanmasına zaman ayırmamakta, sadece zaman geçirecek, ders suresini dolduracak davranışlar göstermektedir.

Öğretmenin eğitim-öğretim ortamını etkili kılması öğrenci başarısında belirleyici olması açısından öğretmenlerin sınıf yönetimi davranışlarının ortaya çıkarılması oldukça önemli görülmektedir.

Tutum, davranışı bilişsel, davranışsal ve hissî yollarla yordayan psikolojik bir kavramdır. Bu üç kavram, birlikte bir uyum ve eşgüdüm içerisinde bireyin sergileyeceği tutumun zemini oluşturur.

Bireyin ahlaki ve değer yargılarıyla ilişkili olan hissî unsurlar; bireyin olaylar karşısında takınacağı tavırda en etkili kavramlardan biridir. Olay, kişi nesne vb. durumlara karşı birey bilgi, deneyim ve inançları noktasında bir tutum ortaya koymaktadır. Söz konusu tutum bireylerin olaylarla ilişkisinde belirleyicidir. "Tutumun konusunu oluşturan kişi, durum, olay veya nesneye ilişkin olarak sahip olunan her türlü bilgi, deneyim, inanç ve düşünceyi içeren zihinsel ya da bilişsel öge tutumun önemli bir kesitini oluşturmaktadır" (Temizkan, 2008: 464).

Tutumların özelliklerinden biri de her tutumun bir yönünün olmasıdır. Birey herhangi bir konuya karşı olumlu ya da olumsuz bir eğilime sahiptir. Tutum olumlu ise nesne, olay ya da kişiye karşı olumlu duygular, değerlendirmeler ve eğilimler; tutum olumsuz ise olumsuz duygular, değerlendirmeler ve eğilimler söz konusudur. Tutumun yönü olumlu olduğu zamanlarda birey tutumun konusuna yaklaşır, olumsuz olduğu durumlarda da tutumun konusundan uzaklaşır (İnceoğlu, 2004: 48). "Her tutumun bir konusu vardır. Her türlü olay, durum, kişi vb. tutumun konusu olabilir. Ayrıca gelenek ve görenekler, çeşitli davranış biçimleri ve günlük hayatta karşılaşılan hemen her şey tutumun konusu olabilmektedir. Bireylerin herhangi bir konuda tutuma sahip olabilmesi için o konuyla ilgili bir tecrübesi olmalıdır" (Temizkan, 2008: 462).

Toplumun öğretmenlerden beklentisi gittikçe artmaktadır. Nitelikli bireyin yetiştirilme sürecinde öğretmen en önemli unsurlardan biridir. Öğretmen eğitimi de yine bu nitelikli bireye katk1 
sağlama noktasında yapılmalıdır. Alanı ile ilgili bilgi ve birikime sahip olmasının temelinde öğretmen; bildiğini öğrenciye aktarma konusunda da eğitimli olmalıdır. Eğitim- öğretim ortamında temel çıktı öğrencidir. Öğrencilerin de nitelikli olarak yetiştirilmesi bilgi birikiminin etkili bir biçimde aktarılması ile mümkün gözükmektedir. Çocuk psikolojisi, öğrenme psikolojisi alanlarını çok iyi bilmenin yanı sıra eğitim-öğretim ortamında öğretmenin sergileyeceği her türlü davranış söz konusu yaş grubundaki öğrencilerin nitelikli olarak yetişmesine/yetişememesine etki etmektedir.

$\mathrm{Bu}$ çerçevede ana dilin öğretilmesinde Türkçe öğretmenlerinin sınıf içi yönetim tarzlarının mesleklerine etkisinin ortaya konması önem arz etmektedir. Bu önem öğretmenlerin yetiştirilme sürecinde mesleklerine olan bakışları, toplumsal olarak mesleklerinin gerekli ve önemli olduğunun bilincine ulaşmaları ve meslekleri dolayısıyla kendilerini sürekli geliştirmek durumunda olduklarına inanmaları ile ilgilidir. Bu amaçla Türkçe öğretmenlerinin otoriter, aldırmaz, takdir edilen veya başıboş sınıf yönetim tarzlarının; mesleki tutumla ilişkisi belirlenmeye çalışılmıştır.

$\mathrm{Bu}$ çalışma ile Türkçe öğretmenlerinin sınıf yönetimi tarzlarını ve öğretmenlik mesleğine ilişkin tutumlarını belirleyip bu iki görüş arasındaki ilişki ortaya çıkarılmaya çalışılmıştır.

$\mathrm{Bu}$ amaçla aşağıdaki sorulara yanıt aranmıştır:

1. Türkçe öğretmenlerinin sınıf yönetimi tarzları nasıldır?

2. Türkçe öğretmenlerinin sınıf yönetimi tarzları cinsiyet, görev yapılan ilçe, eğitim durumu ve k1deme göre değişmekte midir?

3. Türkçe öğretmenlerinin mesleki tutumlarına ilişkin görüşleri nasıldır?

4. Türkçe öğretmenlerinin mesleki tutumları cinsiyet, görev yapılan ilçe, eğitim durumu ve kıdeme göre değişmekte midir?

5. Türkçe öğretmenlerinin sınıf yönetimi tarzları ile mesleki tutumlarına ait görüşleri arasında nasıl bir ilişki vardır?

\section{Yöntem}

\section{Araştırmanın Modeli}

$\mathrm{Bu}$ araştırmada, ortaokullarda görev yapan Türkçe öğretmenlerinin sınıf yönetimi tarzları ve mesleki tutumlarına ilişkin görüşlerinde nicel araştırma yaklaşımı benimsenmiş olup mevcut durum belirlenmeye çalışıldığından ilişkisel tarama modelinde desenlenmiştir.

\section{Örneklem / Araştırma grubu}

$\mathrm{Bu}$ araştırmanın evrenini Bursa ili merkez ilçelerindeki ortaokullarda görev yapan 876 (Nilüfer: 219, Osmangazi: 399, Yıldırım: 258) Türkçe öğretmeni oluşturmaktadır. Örneklem büyüklügüünün belirlenmesinde Cohran'ın örneklem büyüklüğü belirleme formülü kullanılmış 0.5 tolerans düzeyi için 267 olduğu görülmüştür (Cohran, 1962 Akt. Balc1, 2011). Anketlerin geri dönüşünde eksiklikler olabileceği düşünülerek 285 öğretmenden görüş alınmasına karar verilmiştir. Katılımcılar seçkisiz olarak belirlenmiş ve araştırma sonucunda, anketlerin geri dönüş oranı istenilen düzeyde gerçekleşmiştir. Yapılan anket ile, 124 bayan öğretmen $(\% 46,4) ; 143$ erkek öğretmen $(\% 53,6)$ olmak üzere toplam 267 katılımcıya ulaşılmıştır. Eğitim durumu bakımından yapılan ankete; lisansüstü mezunları $21(\% 8)$, eğitim fakültesi mezunları $222(\% 83)$, eğitim enstitüsü mezunları $8(\% 3)$ ve fen- edebiyat fakültesi mezunları $16(\% 6)$ oranında katılım göstermişlerdir. İlçeler bakımından ise yapılan ankete: Nilüfer: 59 kişi (\%22), Osmangazi 147 (\%55) ve Yıldırım: 61 (\%23) oranlarında katılım göstermişlerdir.

\section{Veri Toplama Araçları}

Araştırmanın verileri "Sınıf Yönetim Tarzı Ölçeği” (Ekici, 2003) ve "Mesleki Tutum Ölçeği”" (Temizkan, 2008) ile toplanmıştır. İlgili ölçekleri kullanılabilmek için M. Temizkan ve G. Ekici' den izin alınmıştır. Sınıf Yönetim Tarzı Ölçeği, Kris (1997) tarafından geliştirilmiş olup Ekici (2004) 
tarafından Türkçeye uyarlanmıştır. Sınıf yönetim tarzını belirleyen ölçek Otoriter Sınıf Yönetimi, Takdir Edilen Sınıf Yönetimi, Başıboş Sınıf Yönetimi ve Aldırmaz Sınıf Yönetimi) ölçmekte ve her sınıf yönetimi tarzı için üçer tane madde bulunmaktadır. Ölçek, "Kesinlikle Aynı Fikirde Değilim" seçeneğinden "Kesinlikle Aynı Fikirdeyim" seçeneğine doğru uzanan beşli Likert tipi yanıt ölçeği ile yanıtlanmaktadır. Ölçekte yer alan alt boyutların Cronbach alfa güvenirlik katsayıları şöyledir: Otoriter Sınıf Yönetimi Tarzı .82, Takdir Edilen Sınıf Yönetimi Tarzı .80, Başıboş Sınıf Yönetimi Tarzı .84, Aldırmaz Sınıf Yönetimi Tarzı .78, Sınıf Yönetimi Tarzları Ölçeği Toplam Cronbach alfa güvenirlik katsayıs1 .87 olarak ifade edilmiştir. Temizkan tarafindan geliştirilip Türkçe öğretmenlerinin mesleki tutumlarını ortaya koyan ölçek Kesinlikle Katılıyorum" seçeneğinden "Kesinlikle Katılmıyorum" seçeneğine doğru uzanan beşli Likert tipi yanıt ölçeği ile yanıtlanmaktadır. Mesleğe ilgi duyma, mesleğe bağll1ık, mesleği sevme, mesleğin gerekliliğine inanma ve meslekle ilgili yeterlilik düzeyleri olmak üzere beş madde altında adlandırılmaya çalışılan ölçeğin Cronbach alfa güvenirlik katsayısı .86 olarak ifade edilmiştir. Her sınıf yönetimi profili için toplam üçer madde bulunmaktadır. Yanıtlayanlar her maddeye 1 ile 5 arasında değer verebilmektedir. Buna göre yanıtlayanların her sınıf yönetimi profil grubundan alabileceği en yüksek puan 15 ve en düşük puan 1'dir. 5'li likert tipi ölçek olarak düzenlenen envanterde maddeler, Kesinlikle Aynı Fikirdeyim (5 puan), Aynı Fikirdeyim (4 puan), Kararsızım (3 puan), Aynı Fikirde Değilim (2 puan), Kesinlikle Aynı Fikirde Değilim (1 puan) olarak derecelendirilmiştir.

\section{Verilerin Analizi}

Katılımcıların görüşlerinin genel olarak değerlendirilmesinde betimsel istatistikler, yüzde, frekans karşılaştırmalarda ise t testi ve tek yönlü varyans analizleri kullanılmıştır. SPSS dağılım normalliği için iki adet test yapar. Grupların sayıları 30'un üzerinde Kolmogorov- Smirnov'a 30'un altında ise Shapiro-Wilk bölümünün p değerlerine bakılır (Can, 2013, s: 88). P değerinin 0.5'ten büyük olması beklenir. Yapılan analiz sonucunda $\mathrm{p}<0.05$ olduğundan testlerin dağılımlarının normal olduğu kabul edilmiştir. Sınıf yönetimi tarzları ile mesleki tutuma ilişkin görüşler arasındaki ilişki ise Pearson korelasyon katsayısı ile belirlenmeye çalışılmıştır. "Korelasyon analizlerinde elde edilen ilişkilerin kuvvetini belirlenmesinde şu aralıklar kullanılmıştır: yüksek 0.70-1.00; orta 0.69-0.30; düşük 0.290.00” (Büyüköztürk, 2012: 35).

\section{Bulgular}

Tablo 1: Türkçe Öğretmenlerinin Sınıf Yönetim Tarzları ile İlgili Betimsel İstatistikler

\begin{tabular}{lcccc}
\hline & $\mathbf{n}$ & $\mathbf{\%}$ & $\overline{\boldsymbol{X}}$ & sd \\
\hline Takdir Edilen & 135 & 50,56 & 9,71 & 2,84 \\
$\begin{array}{l}\text { Sinıf Yönetimi } \\
\text { Otoriter Sinıf }\end{array}$ & 104 & 38,95 & 7,48 & 2,63 \\
$\begin{array}{l}\text { Yönetimi } \\
\text { Aldırmaz Sinıf }\end{array}$ & 16 & 6 & 1,15 & 2,2 \\
$\begin{array}{l}\text { Yönetimi } \\
\text { Başıoş Sınıf }\end{array}$ & 12 & 4,49 & 0,86 & 2,46 \\
Yönetimi & 12 & & \\
\hline
\end{tabular}

Tablo 1'de de görüldüğü üzere sınıf yönetim tarzlarına ait ankete Türkçe öğretmenlerinin verdiği cevapların yüzdeleri: \%50,56'sı takdir edilen sınıf yönetimi, $\% 38.95$ 'i otoriter sınıf yönetimi, \%6'sı ise aldırmaz sınıf yönetimi, \%4,49'u ise başıboş sınıf yönetimi tarzına sahiptir. Türkçe öğretmenlerinin dört sınıf yönetimi tarzı ile ilgili görüşleri "Aynı Fikirdeyim” yanıtına daha yakındır. 
Tablo 2'de görüldüğü gibi araştırmaya katılan Türkçe öğretmenlerinin Takdir edilen $[\mathrm{t}(265)=10,87 ; \mathrm{p}<0.05] ;$ otoriter $[\mathrm{t}(265)=7,98 ; \mathrm{p}<0.05]$; aldırmaz $[\mathrm{t}(258)=.227 \mathrm{p}<0.05]$ ve başıboş $[\mathrm{t}(261)=0.27 ; \mathrm{p}>0.05]$ sinıf yönetimi tarzları cinsiyet değişkenine göre sadece takdir edilen ve otoriter sınıf yönetimi tarzlarında farklılık göstermiştir. Aldırmaz ve başıboş sınıf yönetim tarzları cinsiyet

Tablo 2: Türkçe Öğretmenlerinin Sınıf Yönetim Tarzlarının Cinsiyet ve Eğitim Durumuna Göre Karşılaştırılması

\begin{tabular}{|c|c|c|c|c|c|c|c|}
\hline & & $\mathbf{n}$ & $\overline{\boldsymbol{X}}$ & $\mathbf{s}$ & sd & $\mathbf{t}$ & p \\
\hline \multirow{3}{*}{ Takdir Edilen Sınıf Yönetimi } & Kadın & 124 & 12,27 & 1,8 & \multirow{2}{*}{267} & \multirow{2}{*}{10,87} & \multirow{2}{*}{.000} \\
\hline & Erkek & 143 & 8,91 & 2,62 & & & \\
\hline & Kadın & 124 & 7,54 & 2,91 & \multirow{2}{*}{267} & \multirow{2}{*}{7,98} & \multirow{2}{*}{.001} \\
\hline Otoriter Sınıf Yönetimi & Erkek & 143 & 10,28 & 2,63 & & & \\
\hline \multirow{3}{*}{ Aldırmaz Sınıf Yönetimi } & Kadın & 124 & 9,56 & 2,23 & \multirow{2}{*}{267} & \multirow{2}{*}{.227} & \multirow{2}{*}{.323} \\
\hline & Erkek & 143 & 9,9 & 2,21 & & & \\
\hline & Kadın & 124 & 10,79 & 2,41 & \multirow{2}{*}{267} & \multirow{2}{*}{.027} & \multirow{2}{*}{.453} \\
\hline Başıboş Sınıf Yönetimi & Erkek & 143 & 10,09 & 2,46 & & & \\
\hline \multirow{3}{*}{ Takdir Edilen Sınıf Yönetimi } & Eğitim Fak. & 222 & 10,32 & 2,89 & \multirow{2}{*}{267} & \multirow{2}{*}{1,56} & \multirow{2}{*}{.395} \\
\hline & Diğer & 24 & 9,97 & 2,63 & & & \\
\hline & Eğitim Fak. & 222 & 10,12 & 3,02 & \multirow{2}{*}{267} & \multirow{2}{*}{.507} & \multirow{2}{*}{.002} \\
\hline \multirow[t]{2}{*}{ Otoriter Sınıf Yönetimi } & Diğer & 24 & 8,25 & 3,76 & & & \\
\hline & Eğitim Fak. & 222 & 9,93 & 2,21 & \multirow{2}{*}{267} & \multirow{2}{*}{.323} & \multirow{2}{*}{.599} \\
\hline \multirow[t]{2}{*}{ Aldırmaz Sınıf Yönetimi } & Diğer & 24 & 9,75 & 2,4 & & & \\
\hline & Eğitim Fak. & 222 & 10,77 & 2,77 & \multirow{2}{*}{267} & \multirow{2}{*}{1,14} & \multirow{2}{*}{.127} \\
\hline Başıboș Sınıf Yönetimi & Diğer & 24 & 11,37 & 1,99 & & & \\
\hline
\end{tabular}

değişkenine göre farklılık ortaya çıkarmamıştır. Türkçe öğretmenleri eğitim durumlarına göre; takdir edilen $[\mathrm{t}(248)=1,56 ; \mathrm{p}>0.05]$; otoriter $[\mathrm{t}(248)=.507 ; \mathrm{p}<0.05]$; aldırmaz $[\mathrm{t}(248)=.323 \mathrm{p}>0.05]$ ve başıboş $[\mathrm{t}(248)=1,14 ; \mathrm{p}>0.05]$ sinıf yönetimi tarzları sadece otoriter sinıf yönetim tarzına göre farklılık göstermiştir. Eğitim fakültesi mezunları $\mathrm{X}=10,12$ iken diğer fakülte mezunlarında söz konusu oran $\mathrm{X}=8,25$ olarak ortaya çıkmıştır. 
Tablo 3: Türkçe Öğretmenlerinin Sınıf Yönetim Tarzlarının Görev Yapılan İlçeye Göre Değerlendirilmesi

\begin{tabular}{lccccccc}
\hline & $\begin{array}{c}\text { Varyansın } \\
\text { Kaynağı }\end{array}$ & $\begin{array}{c}\text { Kareler } \\
\text { Toplamı }\end{array}$ & sd & $\begin{array}{c}\text { Kareler } \\
\text { Ort. }\end{array}$ & f & p & $\begin{array}{c}\text { Anlamlı } \\
\text { Fark }\end{array}$ \\
\hline $\begin{array}{l}\text { Otoriter } \\
\text { Sınıf }\end{array}$ & Gruplar Arası & 17,029 & 3 & & & & \\
Yönetimi & Gruplar İçi & 2501,383 & 264 & 9,475 & 0,899 & 0,408 & - \\
\hline Toplam & 2518,412 & 267 & & & & \\
Başıboş & Gruplar Arası & 12,711 & 3 & & & & \\
Sinıf & Gruplar İçi & 1614,503 & 264 & 6,116 & 1,039 & 0,355 & - \\
Yönetimi & Toplam & 1627,213 & 267 & & & & \\
\hline Aldırmaz & Gruplar Arası & 7,626 & 3 & & & & \\
Sinıf & Gruplar İçi & 1068,442 & 264 & 4,047 & 0,942 & 0,391 & - \\
Yönetimi & Toplam & 1076,067 & 267 & & & & \\
\hline Takdir & Gruplar Arası & 16,724 & 3 & & & & \\
Edilen & Gruplar İçi & 2221,441 & 264 & 8,415 & 0,694 & .502 & \\
Sinıf & Toplam & 2238,165 & 267 & & & & \\
Yönetimi & Tom & & & & & \\
\hline
\end{tabular}

Türkçe öğretmenlerinin sınıf yönetim tarzları görev yapılan ilçeye göre: Otoriter sınıf yönetimi $\left[\mathrm{F}_{(2-264)}=.899 ; \mathrm{p}>0.05\right]$, başıboş sınıf yönetimi $\left[\mathrm{F}_{(2-264)}=1.039 ; \mathrm{p}>0.05\right]$, aldırmaz sınıf yönetimi $\left[\mathrm{F}_{(2-}\right.$ $264)=.942 ; \mathrm{p}>0.05]$ ve takdir edilen sınıf yönetimi $\left[\mathrm{F}_{(2-264)}=.694 ; \mathrm{p}>0.05\right]$ bakımından anlamlı fark göstermemiştir.

Tablo 4: Türkçe Öğretmenlerinin Sınıf Yönetim Tarzlarının Kıdeme Göre Değerlendirilmesi

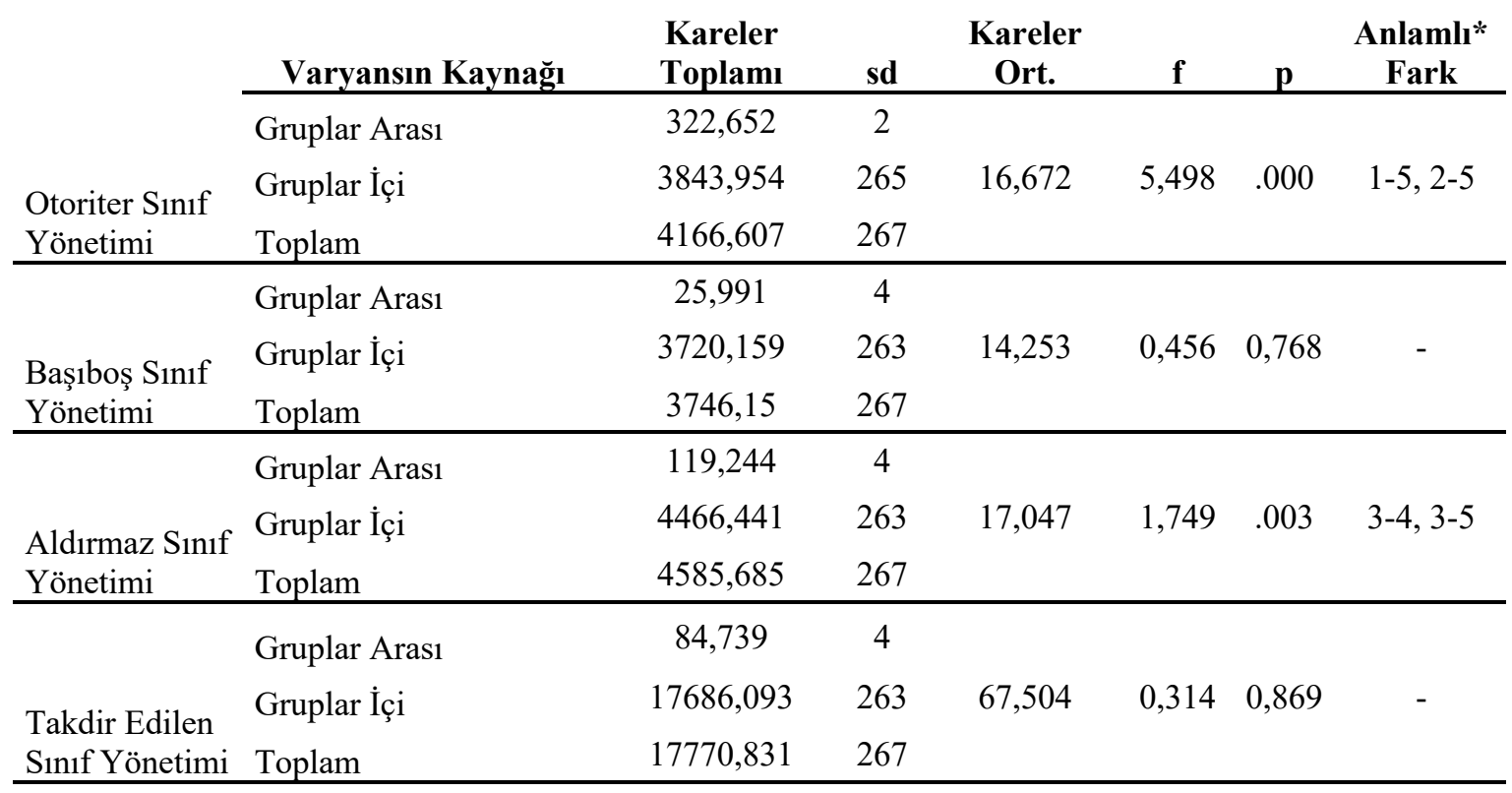

*1: 1-5 Y1l 2: 6-10 Yil 3: 11-15 Yil 4: 16-20 Yil 5: 21 Yil ve Üstü 
Sınıf yönetim tarzları kıdem değişkeninde; otoriter $\left[\mathrm{F}_{(2-264)}=5.498 ; \mathrm{p}<0.05\right]$ ve aldırmaz sınıf yönetim tarzlarına $\left[\mathrm{F}_{(4-264-2)}=1.749 ; \mathrm{p}<0.05\right]$, göre anlamlı fark gösterirken başıboş $\left[\mathrm{F}_{(4-261)}=.456 ; \mathrm{p}>0.05\right]$, ve takdir edilen $\left[\mathrm{F}_{(4-262)}=.314 ; \mathrm{p}>0.05\right]$, sınıf yönetim tarzları bağlamında anlamlı fark göstermemiştir. Otoriter sinıf yönetim tarzı istatistiksel olarak; 1-5 y1l $(X=8,5), 6-10$ yıl $(X=8,3), 21$ yıl ve üstü $(X=5,33)$ şeklinde ortaya çıkmıştır. 21 yıl ve üstü kıdeme sahip olan Türkçe öğretmenleri, 1-10 yıl kıdeme sahip olan öğretmenlere göre farklılık göstermiştir. Aynı şekilde aldırmaz sınıf yönetim tarzı; 11-15 yıl (X=8,3), 16-20 $(X=7,2), 21$ yıl ve üstü $(X=7,41)$ şeklinde ortaya çıkmıştır. 16 yıl ve üzeri kıdeme sahip olan Türkçe öğretmenleri, aldırmaz sınıf yönetim anlayışını benimsemişlerdir.

Tablo 5: Türkçe Öğretmenlerinin Meslekî Tutumları

\begin{tabular}{|c|c|c|c|c|c|c|c|c|c|c|}
\hline & \multicolumn{2}{|c|}{$5 *$} & \multicolumn{2}{|c|}{$4 *$} & \multicolumn{2}{|c|}{ 3* } & \multicolumn{2}{|c|}{$2 *$} & \multicolumn{2}{|c|}{$1 *$} \\
\hline Mesleğe İlgi Duyma & $\mathrm{f}$ & $\%$ & $\mathbf{f}$ & $\%$ & $\mathbf{f}$ & $\%$ & $\mathbf{f}$ & $\%$ & $\mathbf{f}$ & $\%$ \\
\hline $\begin{array}{l}\text { Türkçe öğretmenliğiyle } \\
\text { ilgili her şey ilgimi } \\
\text { çeker. }\end{array}$ & 137 & 51,3 & 104 & 39 & 16 & 5,99 & 10 & 3,75 & 0 & 0 \\
\hline $\begin{array}{l}\text { Sürekli okumayı ve } \\
\text { araştırmayı gerektirdiği } \\
\text { için Türkçe } \\
\text { öğretmenliğine karşı } \\
\text { soğuk duruyorum. }\end{array}$ & 1 & 0,37 & 9 & 3,37 & 24 & 8,99 & 101 & 37,8 & 132 & 49,4 \\
\hline $\begin{array}{l}\text { Boş zamanlarımda } \\
\text { Türkçe öğretmenliğiyle } \\
\text { ilgili çalışmalar } \\
\text { yaparım. }\end{array}$ & 84 & 31,5 & 130 & 48,7 & 29 & 10,9 & 24 & 8,99 & 0 & 0 \\
\hline $\begin{array}{l}\text { Türkçe öğretmeninin } \\
\text { mesleği boyunca } \\
\text { kendini sürekli } \\
\text { geliştirmesi gerektiğini } \\
\text { düşünüyorum. }\end{array}$ & 166 & 62,2 & 80 & 30 & 12 & 4,49 & 9 & 3,37 & 0 & 0 \\
\hline Mesleğe Bağlılık & & & & & & & & & & \\
\hline $\begin{array}{l}\text { Mümkün olsa Türkçe } \\
\text { öğretmenliği yerine } \\
\text { başka bir mesleği } \\
\text { seçerdim. }\end{array}$ & 17 & 6,37 & 28 & 10,5 & 34 & 12,7 & 116 & 43,4 & 72 & 27 \\
\hline $\begin{array}{l}\text { Maddi yönü } \\
\text { iyileştirilirse Türkçe } \\
\text { öğretmenliğini daha } \\
\text { büyük zevkle yaparım. }\end{array}$ & 64 & 24 & 81 & 30,3 & 37 & 13,9 & 68 & 25,5 & 17 & 6,37 \\
\hline $\begin{array}{l}\text { Benim için en uygun } \\
\text { mesleğin Türkçe } \\
\text { öğretmenliği olduğuna } \\
\text { inanıyorum. }\end{array}$ & 65 & 24,3 & 61 & 22,8 & 98 & 36,7 & 33 & 12,4 & 10 & 3,75 \\
\hline $\begin{array}{l}\text { Okuldaki eğitim ve } \\
\text { öğrencilerin } \\
\text { yetiştirilmesi açısından }\end{array}$ & & & & & & & & & & \\
\hline $\begin{array}{l}\text { Türkçe öğretmenliği, } \\
\text { diğer dal } \\
\text { öğretmenliklerinden } \\
\text { daha önemlidir. }\end{array}$ & 67 & 25,1 & 89 & 33,3 & 44 & 16,5 & 58 & 21,7 & 9 & 3,37 \\
\hline $\begin{array}{l}\text { Eğitim fakültesi } \\
\text { mezunu olmayanların }\end{array}$ & 108 & 40,4 & 49 & 18,4 & 24 & 8,99 & 68 & 25,5 & 18 & 6,74 \\
\hline
\end{tabular}


Türkçe öğretmenliği

yapmasını doğru

bulmuyorum.

Mesleği Sevme

Türkçe öğretmenliği

zevk alarak

yapilabilecek bir

130

$48,7 \quad 81$

$81 \quad 30,3 \quad 40$

15

$15 \quad 5,62 \quad 1$

0,37

meslektir.

Türkçe öğretmenliğinin

öğrencilere sevgi,

doğruluk vb. erdemleri

öğretebilmek için iyi

$\begin{array}{llllllllll}127 & 47,6 & 98 & 36,7 & 15 & 5,62 & 26 & 9,74 & 1 & 0,37\end{array}$

bir meslek olduğunu

düşünüyorum.

Türkçe öğretmenliğinin

manevi doyumu diğer

mesleklere göre daha

$\begin{array}{llllllllll}51 & 19,1 & 103 & 38,6 & 58 & 21,7 & 53 & 19,9 & 2 & 0,75\end{array}$

yüksektir.

Mesleki Gerekliliğe

İnanma

Türkçe öğretmenliğinin

toplumdaki değerini

kaybettiğini

66

$24,7 \quad 70$

$26,2 \quad 58$

$21,7 \quad 44$

$16,5 \quad 29$

10,9

düşünüyorum.

Okullarda demokratik

bir öğrenme ortamının

sağlanmasında Türkçe

öğretmenliğinin payı en

62

$23,2 \quad 108$

40,4

44

16,5

53

$19,9 \quad 0 \quad 0$

büyüktür.

Öğrencileri hayata

hazırlamada Türkçe

öğretmenlerine çok

büyük görevler

$\begin{array}{llllllllll}115 & 43,1 & 135 & 50,6 & 17 & 6,37 & 0 & 0 & 0 & 0\end{array}$

düşmektedir.

Dilin kirlenmesine

karşı Türkçe öğretmeni

olarak şu anki

durumumdan daha iyi

mücadele

93

edebileceğime

inaniyorum.

Mesleki Yeterlilik

Türkçe öğretmenliği

öğretim

teknolojilerinden en üst

düzeyde yararlanmayı

gerektirir

Kendimi alan bilgisi

dersleri açısından

yetersiz görüyorum.

Kendimi mesleki

formasyon açısından

yeterli bulmuyorum.

$\begin{array}{llllllllll}93 & 34,8 & 112 & 41,9 & 20 & 7,49 & 34 & 12,7 & 8 & 3\end{array}$

Kendimi öğretim

yöntem ve tekniklerini

$\begin{array}{rrrrrrrrrr}2 & 0,75 & 35 & 13,1 & 11 & 4,12 & 115 & 43,1 & 104 & 39 \\ 19 & 7,12 & 23 & 8,61 & 14 & 5,24 & 100 & 37,5 & 111 & 41,6 \\ 1 & 0,37 & 33 & 12,4 & 14 & 5,24 & 113 & 42,3 & 106 & 39,7\end{array}$

Turkish Studies - Education, 15(2) 
Türkçe Öğretmenlerinin Sınıf Yönetim Tarzları ile Öğretmenlik Mesleğine Yönelik Tutumları...1339

etkili kullanacak

düzeyde

hissetmiyorum.

Lisansta almış olduğum

Okul Deneyimi ve

Öğretmenlik

Uygulaması derslerinin

ögrretmenlik yaparken

62

23

yararlı olduğunu

düşünüyorum.

Lisans eğitimi

esnasındaki alan

derslerinin yetersiz

$23,2 \quad 114$

42,7

21

7,87

56

$21 \quad 14$

5,24

olduğunu

düşünüyorum.

5: Kesinlikle Aynı Fikirdeyim 4: Aynı Fikirdeyim 3: Kararsızım 2: Aynı Fikirde Değilim 1: Kesinlikle Aynı Fikirde Değilim

Türkçe öğretmenlerinin öğretmenlik mesleğine karşı tutumları ile ilgili cevaplar "Kesinlikle Aynı Fikirdeyim" ve "Aynı Fikirdeyim" cevaplarını daha yakındır. Lisans eğitimi esnasında edinilen becerilerin Türkçe öğretmenliği yaparken işe yaramadığını ifade eden öğretmen sayısı oldukça fazladır. Aynı şekilde maddi yönün iyileştirilmesi gerektiğini düşünen öğretmen sayısı, eğitim fakültesi mezunu olmayan öğretmenlerin Türkçe öğretmenliği yapmasını istemeyen sayısı da oldukça yüksektir. Gerek alınan eğitim gerekse eğitim fakültesi mezunu öğretmenlerin iş bulma kaygısı bu seçeneğin artmasını sağlamış olabilir. Aynı şekilde fen-edebiyat mezunlarının öğretmen olarak atanmasının kendilerine yapılan bir haksızlık olduğunun düşünülmesi de fen-edebiyat mezunları ile ilgili maddenin frekansını arttırmış olabilir.

Tablo 6: Türkçe Öğretmenlerinin Mesleki Tutumlarının Cinsiyet ve Eğitim Durumuna Göre Karşılaştırılması

\begin{tabular}{|c|c|c|c|c|c|c|c|}
\hline & & n & $\overline{\boldsymbol{X}}$ & $\mathbf{S}$ & sd & $\mathbf{t}$ & p \\
\hline \multirow{2}{*}{$\begin{array}{l}\text { Mesleğe İlgi } \\
\text { Duyma }\end{array}$} & Kadın & 124 & 8,024 & 3,98 & & & \\
\hline & Erkek & 143 & 6,54 & 4,35 & 267 & .633 & .000 \\
\hline \multirow{2}{*}{ Mesleğe Bağl1lık } & Kadın & 124 & 8,83 & 3,76 & & & \\
\hline & Erkek & 143 & 8,87 & 3,78 & 267 & .086 & .618 \\
\hline \multirow{2}{*}{ Mesleği Sevme } & Kadın & 124 & 8,65 & 5,64 & & & \\
\hline & Erkek & 143 & 9,48 & 3,76 & 267 & .673 & .787 \\
\hline \multirow{2}{*}{$\begin{array}{l}\text { Mesleki } \\
\text { Gerekliliğe İnanma }\end{array}$} & Kadın & 124 & 7,65 & 4,05 & & & \\
\hline & Erkek & 143 & 7,87 & 4,24 & 267 & .432 & .632 \\
\hline \multirow{2}{*}{ Mesleki Yeterlilik } & Kadın & 124 & 8,9 & 3,58 & & & \\
\hline & Erkek & 143 & 8,31 & 3,58 & 267 & 1,33 & .782 \\
\hline \multirow{2}{*}{$\begin{array}{l}\text { Mesleğe İlgi } \\
\text { Duyma }\end{array}$} & Eğitim Fak. & 222 & 9,85 & 2,98 & & & \\
\hline & Diğer & 24 & 8,97 & 2,59 & 267 & 1,46 & .495 \\
\hline \multirow{2}{*}{ Mesleğe Bağlılık } & Eğitim Fak. & 222 & 9,95 & 3,12 & & & \\
\hline & Diğer & 24 & 10,05 & 3,84 & 267 & .507 & .584 \\
\hline Mesleği Sevme & Eğitim Fak. & 222 & 8,96 & 2,56 & 267 & .323 & .652 \\
\hline
\end{tabular}




\begin{tabular}{llcccccc} 
& Diğer & 24 & 8,56 & 2,49 & & & \\
Mesleki & Eğitim Fak. & 222 & 11,25 & 2,79 & & & \\
Gerekliliğe İnanma & Diğer & 24 & 10,94 & 1,96 & 267 & 1,14 & .151 \\
\multirow{2}{*}{ Mesleki Yeterlilik } & Eğitim Fak. & 222 & 11,05 & 3,15 & & & \\
& Diğer & 24 & 10,89 & 3,58 & 267 & 1,17 & .387 \\
\hline
\end{tabular}

Türkçe öğretmenlerinin öğretmenlik mesleğine karşı tutumları cinsiyet değişkenince sadece mesleğe ilgi duyma [t(265)=.633; $\mathrm{p}<0.05]$ başlığında yer alan dört madde (Türkçe öğretmenliğiyle ilgili her şey ilgimi çeker, Boş zamanlarımda Türkçe öğretmenliğiyle ilgili çalışmalar yapmaktan hoşlanırım, Sürekli okumayı ve araştırmayı gerektirdiği için Türkçe öğretmenliğinden hoşlanmıyorum, İyi bir Türkçe öğretmeninin mesleği boyunca kendini geliştirmesi gerektiğine inanıyorum) bakımından bayan öğretmenler lehine anlamlı fark göstermiştir. Mesleğe bağlılık $[\mathrm{t}(265)=.086 ; \mathrm{p}>0.05]$, mesleği sevme $[\mathrm{t}(258)=.673 ; \mathrm{p}>0.05]$, mesleki gerekliliğe inanma $[\mathrm{t}(261)=.432 ; \mathrm{p}>0.05] \mathrm{ve}$ mesleki yeterlilik $[\mathrm{t}(248)=1.14 ; \mathrm{p}>0.05]$ bakımından anlamlı fark göstermemiştir. Aynı şekilde öğretmenlik mesleğine karşı tutum, eğitim durumuna göre: Mesleğe ilgi duyma $[\mathrm{t}(248)=1.46 ; \mathrm{p}<0.05]$, mesleğe bağl1l1k $[\mathrm{t}(248)=.507 ; \mathrm{p}>0.05]$, mesleği sevme $[\mathrm{t}(248)=.323$; $\mathrm{p}>0.05]$, mesleki gerekliliğge inanma $[\mathrm{t}(248)=1.14 \mathrm{p}>0.05]$ ve mesleki yeterlilik $[\mathrm{t}(248)=1.17 ; \mathrm{p}>0.05]$ herhangi bir anlamlı fark göstermemiştir.

Tablo 7: Türkçe Öğretmenlerinin Mesleki Tutumlarının Görev Yapılan İlçeye Göre Değerlendirilmesi

\begin{tabular}{clccccccc}
\hline & Varyansın Kaynağı & $\begin{array}{c}\text { Kareler } \\
\text { Toplamı }\end{array}$ & sd & Kareler Ort. & f & p & $\begin{array}{c}\text { Anlamlı } \\
\text { Fark }\end{array}$ \\
\cline { 2 - 8 } & Gruplar Arası & 15,403 & 3 & & & & & \\
Mesleğe İlgi & Gruplar İçi & 2101,383 & 264 & 8,48 & 0,699 & .618 & - \\
Duyma & Toplam & 2116,786 & 267 & & & & \\
& Gruplar Arası & 14,711 & 2 & & & & \\
Mesleğe & Gruplar İçi & 1814,503 & 265 & 5,12 & 1,069 & .425 & - \\
Bağl1lik & Toplam & 1829,213 & 267 & & & & \\
& Gruplar Arası & 6,626 & 3 & & & & \\
Mesleği & Gruplar İçi & 1268,442 & 264 & 3,16 & 0,716 & .581 & - \\
Sevme & Toplam & 1275,067 & 267 & & & & \\
Mesleki & Gruplar Arası & 18,724 & 3 & & & & \\
Gerekliliğe & Gruplar İçi & 2361,441 & 264 & 7,63 & 0,787 & .318 & - \\
İnanma & Toplam & 2380,165 & 267 & & & & \\
& Gruplar Arası & 18,991 & 3 & & & & \\
Mesleki & Gruplar İçi & 2930,159 & 264 & 10,3 & 1,016 & .581 & - \\
Yeterlilik & Toplam & 2949,15 & 267 & & & & \\
\hline
\end{tabular}

Türkçe öğretmenlerinin mesleki tutumları görev yapılan ilçeye göre: Mesleği ilgi duyma [F(2$264)=.699 ; \mathrm{p}>0.05]$, mesleğe bağll1ık $[\mathrm{F}(2-264)=1.069 ; \mathrm{p}>0.05]$, mesleği sevme $[\mathrm{F}(2-264)=.716$; $\mathrm{p}>0.05]$ mesleki gerekliliğe inanma $[\mathrm{F}(2-264)=.787 ; \mathrm{p}>0.05]$ ve mesleki yeterlilik $[\mathrm{F}(2-264)=1.016$; $\mathrm{p}>0.05$ ] bakımından anlamlı fark göstermemiştir. 
Türkçe Öğretmenlerinin Sınıf Yönetim Tarzları ile Öğretmenlik Mesleğine Yönelik Tutumları...1341

Tablo 8: Türkçe Öğretmenlerinin Mesleki Tutumlarının Kıdeme Göre Değerlendirilmesi

\begin{tabular}{lccccccc}
\hline & Varyansın Kaynağı & Kareler Toplamı & sd & $\begin{array}{c}\text { Kareler } \\
\text { Ort. }\end{array}$ & f & p & $\begin{array}{c}\text { Anlamlı } \\
\text { Fark* }\end{array}$ \\
& Gruplar Arası & 22,652 & 3 & & & & \\
Mesleğe İlgi & Gruplar İçi & 3043,954 & 264 & 10,152 & 3,398 & .000 & $1-5,1-4$ \\
Duyma & Toplam & 3066,607 & 267 & & & & \\
& Gruplar Arası & 21,991 & 4 & & & & \\
Mesleğe & Gruplar İçi & 2720,159 & 263 & 12,253 & 0,486 & .000 & $1-2,1-3$ \\
Bağll11k & Toplam & 2742,15 & 267 & & & & \\
& Gruplar Arası & 84,739 & 4 & & & & \\
Mesleği & Gruplar İçi & 17686,093 & 263 & 67,504 & 0,314 & 0,87 & - \\
Sevme & Toplam & 17770,831 & 267 & & & & \\
Mesleki & Gruplar Arasi & 129,244 & 3 & & & & \\
Gerekliliğe & Gruplar İçi & 4636,441 & 264 & 16,038 & 1,309 & .032 & - \\
İnanma & Toplam & 4765,685 & 267 & & & & \\
& Gruplar Arasi & 14,991 & 2 & & & & \\
Mesleki & Gruplar İçi & 2120,159 & 265 & 10,201 & .656 & 0,47 & - \\
Yeterlilik & Toplam & 2135,15 & 267 & & & & \\
\hline
\end{tabular}

*1: 1-5 Y11 2: 6-10 Y11 3: 11-15 Y1l 4: 16-20 Y1l 5: 21 Yil ve Üstü

Türkçe öğretmenlerinin mesleki tutumları kıdem değişken bakımından; mesleğe ilgi duyma başlığında yer alan dört madde (Türkçe öğretmenliğiyle ilgili her şey ilgimi çeker, Boş zamanlarımda Türkçe öğretmenliğiyle ilgili çalışmalar yapmaktan hoşlanırım, Sürekli okumayı ve araştırmayı gerektirdiği için Türkçe öğretmenliğinden hoşlanmıyorum, İyi bir Türkçe öğretmeninin mesleği boyunca kendini geliştirmesi gerektiğine inanıyorum) ve mesleğe bağlllık başlığında yer alan dört madde (Eğitim fakültesi mezunu olmayanların Türkçe öğretmenliği yapmasını doğru bulmuyorum, Okuldaki eğitim ve öğrencilerin yetiştirilmesi açısından Türkçe öğretmenliği, diğer dal öğretmenliklerinden daha önemlidir, Maddi yönü iyileştirilirse Türkçe öğretmenliğini daha büyük zevkle yaparım ve Mümkün olsa Türkçe öğretmenliği yerine başka bir mesleği seçerdim) maddeleri bağlamında anlamlı fark göstermiştir. Mesleği sevme $\left[\mathrm{F}_{(4-262)}=.314 ; \mathrm{p}>0.05\right]$, mesleki gerekliliğe inanma $\left[\mathrm{F}_{(2-263)}=1.309 ; \mathrm{p}>0.05\right]$ ve mesleki yeterlilik $\left[\mathrm{F}_{(2-261)}=.656 ; \mathrm{p}>0.05\right]$, k1dem değişkenince anlamlı fark göstermemiştir. Mesleğe ilgi duyma $\left[\mathrm{F}_{(2-263)}=3.398 ; \mathrm{p}<0.05\right]$, kıdem bağlamında; $1-5$ y1l $(X=6,3)$ olumsuz görüş ortaya sunarken, $11-15$ yıl $(X=8,3)$ ve 16-20 y1l $(X=8,7)$ kıdeme sahip öğretmenlerde anlamlı fark ortaya çıkmıştır. Diğer kıdemdeki Türkçe öğretmenlerinde mesleğe ilgi duyma alt boyutunda fark olsa da söz konusu fark istatistiksel olarak anlamlı değildir. 1-5 yıl kıdeme sahip Türkçe öğretmenleri ile 6-15 y1l kıdeme sahip Türkçe öğretmenleri arasında mesleğe bağl1lık alt boyutunda farklılıklar vardır. Mesleğe bağlılık $\left[\mathrm{F}_{(4-261)}=.486 ; \mathrm{p}<0.05\right]$, kıdem bağlamında; $1-5$ y1 $(X=5,4)$ öğretmenleri olumsuz görüş bildirirken 6-10 yıl $(X=10,1)$ ve 11-15 yıl $(X=10,8)$ kıdeme sahip Türkçe öğretmenleri arasında farklılık belirlenmiştir. Diğer kıdeme sahip Türkçe öğretmenleri noktasında mesleğe bağlılık alt boyutunda istatistiksel olarak anlamlı bir sonuç belirlenememiştir. 
Tablo 9: Türkçe Öğretmenlerinin Sınıf Yönetim Tarzlarının Mesleki Tutumları ile İlişkisi

\begin{tabular}{|c|c|c|c|c|c|c|c|c|c|c|}
\hline \multirow{3}{*}{ Sınıf Yönetim Tarzları } & \multicolumn{10}{|c|}{ Öğretmenlik Tutum } \\
\hline & \multicolumn{2}{|c|}{$\begin{array}{l}\text { Mesleğe İlgi } \\
\text { Duyma }\end{array}$} & \multicolumn{2}{|c|}{$\begin{array}{l}\text { Mesleğe } \\
\text { Bağlılık }\end{array}$} & \multicolumn{2}{|c|}{$\begin{array}{c}\text { Mesleği } \\
\text { Sevme }\end{array}$} & \multicolumn{2}{|c|}{$\begin{array}{c}\text { Mesleki } \\
\text { Gerekliliğe } \\
\text { İnanma }\end{array}$} & \multicolumn{2}{|c|}{$\begin{array}{c}\text { Mesleki } \\
\text { Yeterlilik }\end{array}$} \\
\hline & $\mathbf{r}$ & $\mathbf{p}$ & $\mathbf{r}$ & $\mathbf{p}$ & $\mathbf{r}$ & $\mathbf{p}$ & $\mathbf{r}$ & $\mathbf{p}$ & $\mathbf{r}$ & $\mathbf{p}$ \\
\hline Takdir Edilen Sınıf Yönetimi & .066 & .286 & .004 & .944 & .791 & $.003 *$ & .027 & .657 & .015 & .808 \\
\hline Otoriter Sınıf Yönetimi & .692 & $.001 *$ & .128 & .030 & .015 & .802 & .752 & $.000^{*}$ & .041 & .506 \\
\hline Aldırmaz Sınıf Yönetimi & .020 & .745 & .010 & .876 & .037 & .551 & .052 & .399 & .081 & .188 \\
\hline Başıboş Sınıf Yönetimi & .061 & .321 & .025 & .688 & .106 & .184 & .095 & .121 & .038 & .533 \\
\hline
\end{tabular}

*Correlation is significant at the 0.05 level (2tailed).

Tablo 9 incelendiğinde Türkçe öğretmenlerinin sınıf yönetim tarzları ile öğretmenlik mesleği tutumları arasında ilişki genel anlamda çok yüksek değildir. Takdir edilen sınıf yönetim tarzı mesleği sevme alt boyutu ile anlamlı bir ilişki ortaya koymuştur. Mesleği sevme $\mathrm{r}=791 \mathrm{p}<.05$. determinasyon katsayısı $\left(\mathrm{r}^{2}=0.62\right)$ dikkate alındığında mesleğe ilgi duyma toplam varyansının \%62'sini açıklamaktadır. Otoriter sınıf yönetim tarzı; "mesleğe ilgi duyma" ve "mesleği gerekliliği inanma" tutum alt boyutlarında arasında ilişki ortaya koymuştur. Mesleğe ilgi duyma, $r=692 \mathrm{p}<.05$. determinasyon katsayısı $\left(\mathrm{r}^{2}=0.47\right)$ dikkate alındığında mesleğe ilgi duyma toplam varyansının $\% 47$ 'sini açıklamaktadır. Mesleki gerekliliğe inanma $\mathrm{r}=752 \mathrm{p}<.05$. determinasyon katsayısı $\left(\mathrm{r}^{2}=0.56\right)$ dikkate alındığında mesleki gerekliliğe inanma toplam varyansın \%56'sını açıklamaktadır. Mesleğini seven Türkçe öğretmenlerinin Takdir edilen sınıf yönetim tarzını benimseme yönüyle pozitif bir ilişki oluşturduğu ifade edilebilir. Aynı şekilde otoriter sınıf yönetim tarzını benimseyen Türkçe öğretmenleri mesleğe ilgi duyma ve mesleki gerekliliğe inanma alt boyutuyla pozitif yönde bir ilişki ortaya koymuştur.

\section{Tartışma}

Hedefler noktasında öğrencilerde davranış değişikliği meydan getirmesi beklenen öğretmen, söz konusu değişikliğin gerçekleşmesi için öğrenme ortamını uygun hâle getirebilmelidir. Eğitimöğretim ortamını verimli hale getirebilmenin temel koşullarından biri de öğretmenin sınıf yönetimine bakış açısı ve sınıf yönetimindeki becerisidir. Bu beceri ekseninde öğretmen sağlıklı ve etkili bir öğrenme ortamı oluşturabilir. "Sınıf yönetiminde adil bir anlayış sergileyen öğretmenler, sınıflarında pozitif bir öğrenme ortamı oluşturdukları gibi öğrenci motivasyonunu da arttırabilirler" (Skipper ve Douglas, 2015: 282). Öğrencilerin sınıf ortamında birbirleriyle olan ilişkileri öğretmenin tarzından etkilenebilmektedir. Öğrenme hedeflerine ulaşabilme ve öğrenme ortamında iş birliğinin gerçekleşmesi de sınıf yönetim becerisi yüksek olan öğretmenlerce sağlanabilir. Öğretmenin öğrenme sürecini farklı boyutlarıyla yönetebilmesi için öncelikle buna inanmış olması gerekir. Çünkü inanmayan öğretmen kendisini motive edemeyeceği gibi öğrencisini de motive edemez. "Farklı ihtiyaç, beklenti ve motivasyona sahip bir sınıf ortamını etkili yönetebilmek öğretmenin öğretmeye olan inancı ile eşdeğerdir" (Deniz ve Erdener, 2016: 28-29). "Öğretmenler, eğitim-öğretim ortamının verimi ve disiplini için öğrencileriyle etkili iletişim kurabilmek için sınıf yönetimi konusuna duyarlılık ve hassasiyetle yaklaşmak zorundadırlar" (Sarıtaş, 2000: 40). Öğrenci öğrenme ortamında iletişimi, pedagojik düzeyi, ihtiyaçları ve öğrenme motivasyonu ile öğretmenin kontrolündedir. Söz konusu kontrolün sağlanması da bu anlamda oldukça önemlidir. Bireye kazandırılması gereken en temel 
becerilerden olan konuşma ve okuduğunu anlama becerisi Türkçe öğretmenleri tarafindan gerçekleştirilmektedir ki bu kazanımın edinilmesi de etkili bir sınıf yönetim tarzı ile mümkündür. "Öğrenim ortamının uygunluğu, öğrencinin öğrendiğini kullanabilme yetisi öğretmenin sinıf yönetimi konusunda gerekli becerilere sahip olmasıyla mümkündür" (Sarı, 2002: 102). Etkili bir iletişime sahip Türkçe öğretmeni; okuma, konuşma ve dinleme becerisi gibi bireyde olması gereken temel becerileri kazandırma konusunda etkili olabilecektir. Öğrenme ortamının olumlu, anlayışlı, değer verilen ve etkili iletişime sahip olması bireyin çok yönlü bir biçimde öğrenmesini sağlayabileceği gibi bireye öz düzenleme becerisi de kazandırabilecektir. "Demokratik bir sınıf ortamı bireyin eleştirel ve üretken düşünme becerisine katkı sağlayacağı gibi öğrencilerde sorumluluk, özgüven ve bağl1lık gibi duyguların da gelişmesine katkı sağlayacaktır” (Dönmez, 2007: 89).

Sınıf yönetim tarzları eğitim durumu değişkenine göre otoriter sınıf yönetim tarzı alt boyutu eğitim fakültesi mezunları lehine anlamlı fark göstermiştir (Tablo 2). Sınıf yönetimi problemleri öğretmenlerin işlerinde zorluk yaşadıkları problemler listesinin başında yer almaktadır. Sınıf yönetimi için çok fazla çaba harcandığı; öğretmenler, öğrenciler, veliler, yöneticiler ve okul çevresindekiler tarafindan kabul gören bir gerçektir (Nelson, 2002). Öğretmenlik mesleğinin ilk dönemlerinde ilk defa karşılaşılan ve farklı öğrenme özellikleri sergileyebilen bir sınıfa hâkim olabilmenin zorlukları, sınıf yönetimi konusunda bazı sorunlar ortaya çıkarmış olabilir. Araştırmaya konu olan Türkçe öğretmenlerinin de benzer sorunlarla karşılaşma olasılığı ve diğer fakülte mezunlarının mesleki kıdemi ve yaşı dolayısıyla araştırma sonucunun eğitim fakültesi mezunları lehine anlamlı fark gösterdiği düşünülmektedir. Sezer, Aktan, Tezci ve Erdener (2017)'in çalışmasında ortaokul öğretmenlerin otoriter sınıf yönetim tarzını daha çok benimsedikleri sonucuna ulaşmışlardır.

Türkçe öğretmenlerinin sınıf yönetim tarzları görev yaptıkları merkezi ilçeler göre herhangi bir anlamlı fark göstermemiştir.

Kidem, birçok meslekte olduğu gibi Türkçe öğretmenliğinde de çok önemlidir. Mesleğin ilk yıllarındaki tavır ve davranış ilerleyen yıllarda farklılık gösterebilmektedir. Bu çerçevede; 1-5 ve 6-10 yıllık kıdeme sahip Türkçe öğretmenleri daha otoriter bir sınıf yönetim anlayışına sahiptirler. 11-15, 16-20 ve 21 yıl üstü Türkçe öğretmenleri arasında çok küçük farklar olsa da istatistiksel olarak anlamlı fark bulunamamıştır (Tablo 4). 1-10 yıl kıdem sahip Türkçe öğretmenleri ile 21 yıl ve üstü kıdem sahip Türkçe öğretmenleri arasında otoriter sınıf yönetimi alt boyutuyla önemli ölçüde fark vardır (Tablo 4). Mesleğinin ilk yıllarında sınıfı kontrol altına almaya çalışan öğretmenin zorlanması muhtemeldir. Gelişen- değişen teknoloji ile yoğrulan bir topluluğun gerek farklı öğrenme anlayışı gerek öz düzenleme becerilerindeki yetersizliği gerek de bireysel farklılıkları, öğretmeni sınıf ortamında otoriter sınıf yönetim anlayışını benimsemeye itmiş olabilir. Araştırmaya katılan kıdemli öğretmenlerin genelinde (11 yıl ve üstü) otoriter sınıf yönetim anlayışı pek tercih edilmemiştir. Bu da kıdemin artmasıyla otoriter sınıf anlayışının terk edildiği sonucunu ortaya çıkarmıştır.

Aldırmaz sınıf yönetimi alt boyutuna göre 11-15 yıl kıdeme sahip Türkçe öğretmenleri ile 16 yıl ve daha fazla kıdeme sahip Türkçe öğretmenleri arasında anlamlı fark bulunmaktadır. Cemaloğlu, Erdemoğlu ve Şahin (2007) araştırmalarında ilköğretim okulu öğretmenlerinin mesleki kıdemleri ile tükenmişlik düzeyleri arasında anlamlı bir ilişki olduğunu belirlemiştir. Söz konusu araştırma büyükşehir sınırları içerinde yapıldığından sonucun Türkçe öğretmenlerinin tükenmişlik düzeyleri ilişkisinin olabileceği anlamına gelebilir. Yine Cemaloğlu ve ark. (2007) mesleki kıdemin artmasının duyarsızlaşma ve duygusal tükenmişlik düzeyini de artırdığını belirtmişlerdir. Sınıfların kalabalık olması, değişen bir nesil, her yıl aynı problemler veya işlerle uğraşılması mesleki heyecanın yitirilmesine yol açmış olabilir. Öğretmenlerin birçoğunda zamanla okullardaki kaynak yetersizlikleri, fiziksel yönden kendini iyi hissetmeme, idare ile çatışma, işine ve iş arkadaşlarına karşı olumsuz duygular besleme, eğitim durumu ve yaş gibi demografik faktörlerden dolayı mesleklerine dair ideallerini kaybetme, isteksizlik ve meslekten soğuma durumları görülmektedir (Byrne, 1991; Friedman 1991; Şişman, 2006; Troman \& Woods, 2000). Durak ve Seferoğlu (2017) yaptıkları 
çalışmada kıdeme göre öğretmenlerin "işe bağlı stresle başa çıkma" ve "iş doyumu" alt boyutlarında anlamlı fark gösterdiği sonucuna ulaşmışlardır. Yine aynı çalışmada mesleki kıdem grubunda 26 ve üstü yıl çalışan öğretmenlerin tükenmişlik puanlarının diğer gruplarınkine göre daha yüksek olduğu belirtilmektedir. Kıdemli öğretmenlerin tükenmişlik düzeyinin bu çerçevede aldırmaz sınıf yönetimi ile kendini gösterdiğini söylemek mümkün olabilir. Yani kıdemin artması çeşitli nedenlerle yorulan öğretmenin sınıf yönetim becerisini etkileyebilmektedir. Kıdemli Türkçe öğretmenlerinin sağlıklı bir sınıf yönetim becerisi gösterememesi bireyin toplum ekseninde ihtiyacı olan temel becerileri edinememe sonucunu doğurabilir. Bu noktada aldırmaz sınıf yönetimi, eğitim- öğretim ortamının niteliğinin düşmesine yol açabileceği gibi öğrencilerin Türkçe dersine karşı tutumlarını da etkileyebilir.

Türkçe öğretmenlerinin öğretmenlik mesleğine karşı tutumlarının da belirlenmeye çalışıldığ araştırmada, Türkçe öğretmenleri cinsiyet değişkenince mesleğe ilgi duyma alt boyutunda bayan öğretmenler lehine fark ortaya çıkarken (Tablo 6) kıdem değişkenince mesleğe ilgi duyma ve mesleğe bağlılık alt boyutunda anlamlı fark ortaya çıkmıştır. Mesleğe ilgi duyma alt boyutunda 1-5 yıl kıdeme sahip Türkçe öğretmenleri ile 11-20 yıl kıdeme sahip Türkçe öğretmenleri arasında; mesleğe bağlılık alt boyutunda ise 1-5 yıl kıdeme sahip Türkçe öğretmenleri ile 6-15 yıl kıdeme sahip Türkçe öğretmenleri arasında anlamlı fark belirlenmiştir. Öğretmenlik mesleği tutum boyutu; görev yapılan ilçe ve eğitim durumu değişkenleri noktasında anlamlı bir fark göstermemiştir.

Öğretmenlerin mesleklerine yönelik duyguları temelde mesleklerinin toplum içim önemli ve gerekli olduğuna inanma ile kendilerini sürekli geliştirerek öğrencilerine faydalı olabilme ilkesi ile temellendirilmelidir. Türkçe, bu çerçeveye yerleştirilmekle birlikte aday Türkçe öğretmelerinin Türkçeyi "ana dil" olarak algılayabilmelerinin sağlanması öğretmenlik tutumunun olumlu yönde geliştirilmesine katkı sağlayabilecektir. İçtimai noktada bireylerin gelişmesine katkı vereceğine inanan aday bir Türkçe öğretmenin mesleki davranışının da olumlu yönde ilerlemesi muhtemeldir. Çeliköz ve Çetin (2004)'e göre öğretmen adayları mesleklerine yönelik olumlu tutumlara sahip olarak yetiştirilebilirlerse, öğretmen olduklarında; görevlerini eksiksiz yerine getirirler, öğrencilere karşı daha olumlu davranışlar sergilerler, araştırmacı olurlar, yaratıcı düşünür ve yenilikleri öğrenme ortamına kolayca aktarırlar. Olumlu tutumları el-yüz hareketlerine yansır ve öğrencileri daha kolay motive ederler, öğrencilere içten ve samimi davranırlar, katı kuralcı olmazlar, zamanlarını etkili kullanırlar, kısacası mesleklerini severek yaparlar, zevk alırlar ve dolayısıyla öğretmenin görev, sorumluluk ve rollerini daha iyi bir şekilde üstlenebilirler. "Öğretmen adaylarının mesleğe yönelik olumlu tutum geliştirmelerinde meslek bilinci edinmeleri etkili görülmektedir. Bu nedenle, öğretmenlik mesleğinin öğretmen adaylarına öğretmenliğin bir uzmanlık mesleği olduğu bilinci kazandırılmalıdır" (Şimşek, 2005: 17). Öğretmenlik mesleği düşünüldüğünde, öğretmenlerin kendilerinden beklenen rolleri yerine getirmelerini etkileyen önemli değişkenler; öğretmenliği sevme, sayg1 duyma ve benimseme özelliklerini olarak ön plana çıkmaktadır (Pehlivan- Baykara, 2008). Aday öğretmenlerin yetişme sürecinde ilgili elemanlar etkili ve nitelikli planlamalıdır. Öğretim üyeleri, program ve ders içerikleri öğretmenlik mesleği noktasında özendirici ve uygulanabilir nitelikte olmalıdır. "Öğrenciler derslerin daha zevkli hale getirilmesini istemektedirler. Öğretim üyeleri dersi günümüz koşullarına uygun bir biçimde anlatmalı ve değişik yöntem tekniklerle öğrencilerine katkı sağlamalıdırlar. Aynı zamanda öğretmen eğitimcisinin temel sorunu, öğretim yöntemlerinin açıklanış biçimi itibariyle fazlasıyla kurama dayalı ve didaktik olmas1 ve monotonluktur" (Aydın, 2005: 52). Kuramlar, ilkeler doğrultusunda yetiştirilen bir aday öğretmenin etkili bir davranış değişikliği söz konusu olmayabilir. Öğrenme ortamında gelişen-değişen teknoloji ile sürekli farklı durumlar oluşturabilecek potansiyelde öğrenci bulunmaktadır. Söz konusu öğrencilere Türkçe dersini etkili bir biçimde öğretebilmek uygulamaya yönelik nitelikli öğrenme ve alanına ait argümanları iyi bilme ile mümkün gözükmektedir. $\mathrm{Bu}$ şekliyle yetişen aday öğretmenin olumsuz bir tutum sergilemesi pek olası değildir. Mesleğinin gerekliliklerini iyi bilen ve bildiğini nasıl öğreteceğini de etkili bir biçimde öğrenen öğretmen, öğretmenlik mesleğine olumlu bir tutumla eğitim-öğretim ortamında yer alacaktır. Örneğin konuşma 
becerisini sadece muhteviyat bakımından kuramsal boyutuyla öğrenen aday Türkçe öğretmeninin öğrencilerine sınıf ortamında konuşma becerisi kazandırması beklenemez. Öğrencilerin konuşma becerisine ait kazanımları edinebilmesi uygulama noktasında tereddüde düşmeyen söz konusu beceriyi kazanmada çeşitli uygulamaları daha önce yapmış bir aday öğretmenle mümkün olabilir.

Türkçe öğretmenlerinin sınıf yönetim tarzları öğretmenlik mesleğine tutum bakımından birbirleriyle ilişkilidir (Tablo 9). Otoriter sınıf yönetim puanı yüksek Türkçe öğretmelerinin mesleğe ilgi duyma ve mesleki gerekliliğe inanma puanları yükseldiği gibi aynı şekilde takdir edilen sınıf yönetim tarzı puanı yüksek olan Türkçe öğretmenlerinin de mesleği sevme puanlarının yükseldiği söylenebilir.

\section{Sonuç ve öneriler}

Türkçe öğretmenlerinin sınıf yönetim tarzları ve öğretmenlik mesleğine karşı tutumlarının belirlenmeye çalışıldığ 1 araştırmada öğretmenlerin geneli takdir edilen ve otoriter sınıf yönetim anlayışına sahiptir (Tablo 1). Bu sonuç Güven ve Akdağ (2002), Ekici (2004, 2006), ve Yılmaz (2011)'ın çalışmalarının sonuçlarıyla örtüşmektedir. Sınıf yönetim tarzları cinsiyet değişkenine göre takdir edilen sınıf yönetim alt boyutu noktasında bayan öğretmenler lehine farklılaşırken otoriter sınıf yönetimi alt boyutunda ise erkek öğretmenler lehine anlamlı fark göstermiştir (Tablo 2). Söz konusu sonuç; Terzi (2001), Yalçınkaya ve Tonbul (2002), Altay (2003), Ekici (2004), ve Yeşilyurt ve Çankaya (2008)'nın çalışmalarıyla benzerlik taşımaktadır. Aynı şekilde sınıf yönetim tarzları cinsiyet değişkenine göre; Doğan ve Burç, (2006), Akın (2007), Sezer, Aktan, Tezci- ve Erdener (2017), Öksüz, Çevik, Babave ve Güven, (2011) ve Yılmaz (2011)'in çalışmalarında da anlamlı fark bulunamamıştır. Sınıf yönetim tarzları ile mesleki tutum arasındaki korelasyon bazı alt başlıklar yönünden pozitif yönde anlamlı ilşki söz konusudur. Mesleği sevme determinasyon katsayısı $\left(\mathrm{r}^{2}=0.62\right)$ dikkate alındığında mesleğe ilgi duyma toplam varyansının \%62'sini açılamaktadır. Otoriter sınıf yönetim tarzı; "mesleğe ilgi duyma" ve "mesleği gerekliliği inanma" tutum alt boyutlarında arasında ilişki ortaya koymuştur. Mesleğe ilgi duyma, determinasyon katsayısı $\left(\mathrm{r}^{2}=0.47\right)$ dikkate alındığında mesleğe ilgi duyma toplam varyansının \%47'sini açıklamaktadır. Mesleki gerekliliğe inanma determinasyon katsayısı $\left(\mathrm{r}^{2}=0.56\right)$ dikkate alındığında mesleki gerekliliğe inanma toplam varyansın \%56'sını açıklamaktadır. Mesleki kıdem arttıkça girilen ders sayısı azaltılabilir. Kıdemli öğretmenlere okul içerisinde okul-veli iş birliği ya da okul- çevre iş birliği noktasında görevlendirme yapılabilir. Kıdemli öğretmenlere ayrıca mesleğe yeni başlayan öğretmenlere rehberlik etme görevi de verilebilir.

Bundan sonra yapılacak araştırmalarda farklı sosyo-ekonomik düzeye sahip okullarda çalışan Türkçe öğretmenlerinin sınıf yönetim tarzları ve mesleki tutumlarının okul yönetimi, okul-veli iş birliği, öğrencilerin akademik düzeyleri çerçevesinde farklılık gösterip göstermediği incelenebilir. Kıdemli öğretmenlerin mesleki tükenmişlik nedenlerini ve çözüm önerilerini içeren yeni yüksek katılım içeren çalışmalar yapılabilir.

\section{Kaynakça}

Akın, U. (2007). Öğretmenlerin sınıf yönetimi becerilerinin çeşitli değişkenler açısından incelenmesi ve ögretmen yetiştirme açısından değerlendirilmesi. XVI. Ulusal Eğitim Bilimleri Kongresi. Tokat: Gaziosmanpaşa Üniversitesi. https://dx.doi.org/10.17679/inuefd.323135

Altay, S. (2003). Illköğretim I. kademede görev yapan sınıf öğretmenlerinin sorumluluğa dayalı sinıf yönetimi yaklaşımlarının incelenmesi. Yayınlanmamış yüksek lisans tezi, Marmara Üniversitesi Sosyal Bilimler İstanbul. https://dx.doi.org/10.31795/baunsobed.581904

Aydın, A. (2008). Sinıf yönetimi. Ankara: Pegem Akademi Yayıncılık.

Balc1, A. (2011). Sosyal bilimlerde araştırma. Ankara: Pegem A Yayıncılık. 
Büyüköztürk, Ş. (2012). Sosyal bilimler için veri analizi elkitabı. Ankara: Pegem A Yayıncılık.

Byrne, B. M. (1991). "Burnout: Investigating the impact of background variables for elementary, intermediate, secondary, and university educators." Teaching and Teacher Education, 7(2), 197-209. https://dx.doi.org/10.1016/0742-051x(91)90027-m

Can, A. (2013). SPSS ile bilimsel araştırma sürecinde nitel veri analizi. Ankara: Pegem Akademi.

Celep, C. (2002). Sinıf yönetimi ve disiplini. Ankara: Anı Yayıncılık.

Cemaloğlu, N. ve Erdemoğlu- Şahin, D. (2007). "Öğretmenlerin mesleki tükenmişlik düzeylerinin farklı değişkenlere göre incelenmesi." Kastamonu Ĕ̆itim Dergisi, 15(2), 465-484. https://dx.doi.org/10.16947/fsmia.502230

Çifçi, M. (2006). Türkçe öğretiminin sorunları. G. Gülsevin ve E. Boz (Ed.), Türkçenin çağdaş sorunları (2. Baskı) 77-134. Ankara: Gazi Kitabevi.

Çelik, H. (2003). Fen bilgisi ve fizik-kimya-biyoloji öğretmenlerinin iş doyumu (Kırıkkale İli Örneği). Yayınlanmamış yüksek lisans tezi, Kırıkkale Üniversitesi Sosyal Bilimler Enstitüsü, Kirikkale.

Çeliköz, N. ve Çetin, F. (2004). "Anadolu öğretmen lisesi öğrencilerinin öğretmenlik mesleğine yönelik tutumlarını etkileyen etmenler." Millı̂ Eğitim Dergisi, (162). https://dx.doi.org/10.21764/maeuefd.651393

Deniz, Ü. ve Erdener, A. (2016). Öğretmenlerin iş motivasyonlarını etkileyen etmenler. Tüfekçi, Ö. K. (Ed.), Sosyal bilimlerde stratejik araştırmalar (ss. 29-41). Saarbrücken: Lambert Academic Publishing.

Doğan-Burç, E. (2006). Illköğretim okulu ögretmenlerinin sınıf yönetimi yeterlilikleri (Hatay ili örneği). Yayınlanmamış Yüksek Lisans Tezi. Abant İzzet Baysal Üniversitesi Sosyal Bilimler Enstitüsü, Bolu.

Dönmez, B. (2007). Sosyal bir sistem olarak sınıf. (ed.M. Şişman ve S. Turan) Sinıf yönetimi içinde. Ankara: Pegem Akademi Yayıncılık.

Durak, H. ve Seferoğlu, S. (2017). “Öğretmenlerde tükenmişlik duygusunun çeşitli değişkenler açisindan incelenmesi." Gefad / Gujgef 37(2), 759-788.

Erden, M. (2003). Sinıf yönetimi (2. baskı). İstanbul: Alkım yayınevi

Ekici, G. (2004). “İlköğretim I. kademe öğretmenlerinin sınıf yönetimi profillerinin değerlendirilmesi." Eğitim ve Bilim, 29(131), 50-60.

Fenwick, D. T. (1998). "Managing space, energy, and self: junior high teachers' experiences of classroom management." Teaching and Teacher Education, 14 (6), 619-631. https://dx.doi.org/10.1016/s0742-051x(98)00012-2

Friedman, I. A. (1991). "High and low burnout schools: School culture aspects of teacher burnout." Journal of Educational Research, 84(6), 325-333. https://dx.doi.org/10.1080/00220671.1991.9941813

Güven, S. ve Akdağ, M. (2002). "İlköğretim ikinci kademe öğretmenlerinin sınıf yönetimi etkinliklerine ilişkin öğrenci algılanı.” Kuram ve Uygulamada Eğitim Yönetimi, 29(29), 6980. https://dx.doi.org/10.14527/9786053644309

İnceoğlu, M. (2004). Tutum, algı, iletişim. Ankara: Elips Kitap.

Karip, E. (2005). Sinıf yönetimi ve disiplini. E. Karip (Edt.), Sınıf yönetimi (s. 1-2). Ankara: Pegem A Yayıncilik. 
Türkçe Öğretmenlerinin Sınıf Yönetim Tarzları ile Öğretmenlik Mesleğine Yönelik Tutumları..1347

Kris, B. (1997). "What is your classroom management profile?" Teacher Talk-A Publication for SecondaryEducationTeachers, 1(2).

Nelson, M. F. (2002). A qualitative study of effective school discipline practices: perceptions of administrators, tenured teachers, and parents in twenty schools. Unpublished $\mathrm{PhD}$ Thesis, East Tennessee State University the Faculty of the Department of Educational Leadership and Policy Analysis, Tennessee.

Öksüz, Y., Çevik, C., Baba, M., \& Güven, E. (2011). "Sınıf öğretmeni adaylarının sınıf yönetimine ilișkin algılarının çeșitli değișkenler açısından incelenmesi." Ondokuz Mayıs Üniversitesi Eğitim Fakültesi Dergisi, 30(2), 99-113. https://dx.doi.org/10.30900/kafkasegt.587686

Pehlivan- Baykara, K. (2008). "Sınıf öğretmeni adaylarının sosyo-kültürel özellikleri ve öğretmenlik mesleğine yönelik tutumları üzerine bir çalışma." Mersin Üniversitesi Eğitim Fakültesi Dergisi, 4(2), 151-168. https://dx.doi.org/10.17860/mersinefd.329743

Sarı, H. (2002). Özel eğitime muhtaç öğrencilerin eğilimleriyle ilgili çağdaş öneriler. Ankara: Pegem Yayınc1lik.

Sarıtaş, M. (2000). Sinlf yönetimi ve disiplinle ilgili kurallar geliştirme ve uygulama. (ed.Leyla Küçükahmet). Sinıf yönetiminde yeni yaklaşımlar içinde. (38-44). Ankara: Nobel Yayıncılık.

Sezer, F., Aktan, S.,Tezci, E., Erdener A-M. ( 2017). Öğretmenlerin yaşam stilleri ve sınıf yönetim profillerinin bazı değişkenler açısından incelenmesi, Turkish Studies (12)33, 167-184. https://dx.doi.org/10.7827/turkishstudies. 12680

Skipper, Y. \& Douglas, K. (2015). “The influence of teacher feedback on children's perceptions of student teacher relationships." British Journal of Educational Psychology, 85(3). 276-288. https://dx.doi.org/10.1111/bjep.12070

Şimşek, H. (2005). "Ortaöğretim alan öğretmenliği tezsiz yüksek lisans programına devam eden öğrencilerin öğretmenlik mesleğine yönelik tutumları." Yüzüncü Yll Üniversitesi Eğitim Fakültesi Dergisi, 2, 1-26. https://dx.doi.org/10.17860/mersinefd.305766

Şişman, M. (2006). Öğretmenliğe giriş. Ankara: Pegem Yayınları.

Temizkan, M. (2008). “Türkçe öğretmeni adaylarının öğretmenlik mesleğine yönelik tutumları üzerine bir araştırma." Türk Eğitim Bilimleri Dergisi, 6(3), 461-486. https://dx.doi.org/10.15285/maruaebd.286490

Terzi, Ç. (2001). Öğretmelerin sınıf yönetimi anlayışlarına ilişkin görüşlerinin belirlenmesi. Yayınlanmamış yüksek lisans tezi, Anadolu Üniversitesi Eğitim Bilimleri Enstitüsü, Eskişehir.

Troman, G., \& Woods, P. (2000). "Careers under stress: Teacher adaptations at a time of intensive reform." Journal of Educational Change, 1(3), 253-275. https://dx.doi.org/10.1007/978-90481-2358-2_7

Yalçınkaya, M. ve Tombul, Y. (2002). "İlköğretim okulu sınıf öğretmenlerinin sınıf yönetimi becerilerine ilişkin alg1 ve gözlemler.” Ege Eğitim Dergisi. 1(2), 96-108. https://dx.doi.org/10.17051/ilkonline.2019.639365

Yeşilyurt, E. \& Çankaya, İ. (2008). "Sınıf yönetimi acısından öğretmen niteliklerinin belirlenmesi." Elektronik Sosyal Bilimler Dergisi, 7(23), 274-295.

Yılmaz, K. (2011). "İlköğretim okulu öğretmenlerinin sınıf yönetimi tarzları ile demokratik değerlere ilişkin görüşleri arasındaki ilişki.” Değerler Eğitimi Dergisi, 9(21), 147-170. https://dx.doi.org/10.34234/ded.536439 